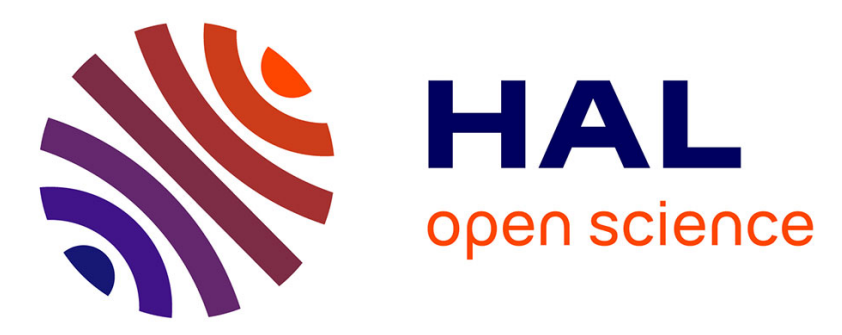

\title{
Biological activities associated to the chemodiversity of the brown algae belonging to genus Lobophora (Dictyotales, Phaeophyceae)
}

Christophe Vieira, Julie Gaubert, Olivier de Clerck, Claude Payri, Gérald Culioli, Olivier Thomas

\section{To cite this version:}

Christophe Vieira, Julie Gaubert, Olivier de Clerck, Claude Payri, Gérald Culioli, et al.. Biological activities associated to the chemodiversity of the brown algae belonging to genus Lobophora (Dictyotales, Phaeophyceae). Phytochemistry Reviews, 2017, 16 (1), pp.1-17. 10.1007/s11101-015-9445-x . hal-01767401

\section{HAL Id: hal-01767401 \\ https: / hal-amu.archives-ouvertes.fr/hal-01767401}

Submitted on 7 May 2018

HAL is a multi-disciplinary open access archive for the deposit and dissemination of scientific research documents, whether they are published or not. The documents may come from teaching and research institutions in France or abroad, or from public or private research centers.
L'archive ouverte pluridisciplinaire HAL, est destinée au dépôt et à la diffusion de documents scientifiques de niveau recherche, publiés ou non, émanant des établissements d'enseignement et de recherche français ou étrangers, des laboratoires publics ou privés. 
1 Biological activities associated to the chemodiversity of the brown algae

4 Christophe Vieira · Julie Gaubert · Olivier De Clerck · Claude Payri • Gérald

5 Culioli $\cdot$ Olivier P. Thomas

$7 \quad$ C. Vieira $(\bowtie)$

8 Sorbonne Universités, UPMC Univ Paris 06, IFD, 4 Place Jussieu, 75252 PARIS

9 cedex 05, France

10 C. Vieira $(\bowtie) \cdot$ Julie Gaubert · C. Payri

11 ENTROPIE, LabEx-CORAIL, Institut de Recherche pour le Développement, B.P.

12 A5, 98848, Nouméa Cedex, Nouvelle-Calédonie, France

13 C. Vieira $(\bowtie) \cdot$ O. De Clerck

14 Phycology Research Group and Center for Molecular Phylogenetics and Evolution,

15 Ghent University, Krijgslaan 281 (S8), B-9000 Gent, Belgium

16 G. Culioli · O. P. Thomas

17 Université Nice Sophia Antipolis, Institut de Chimie de Nice, UMR 7272 CNRS,

18 Faculté des Sciences, Parc Valrose 06108 Nice, France

19 G. Culioli

20 Université de Toulon, MAPIEM, EA 4323, La Garde, France

21 O. P. Thomas

22 Institut Méditerranéen de Biodiversité et d'Ecologie marine et continentale (IMBE),

23 Aix Marseille Université, CNRS, IRD, Avignon Université, Station marine

24 d'Endoume, rue de la Batterie des Lions, 13007 Marseille, France

25 e-mail: cvcarp@gmail.com

27 Running title Bioactivity of natural products of the genus Lobophora 
31 Abstract Although Lobophora belongs to a marine algal family (Dictyotaceae)

32 that produces a large array of secondary metabolites, it has received little attention

33 compared to other genera, such as Dictyota, in terms of natural compounds isolation

34 and characterization. However, metabolites produced by Lobophora species have

35 been found to exhibit a wide array of bioactivities including pharmacological (e.g.

36 antibacterial, antiviral, antioxidant, antitumoral), pesticidal, and ecological. This

37 review aims to report the state-of-the-art of the natural products isolated from

38 Lobophora species (Dictyotales, Phaeophyceae) and their associated bioactivities. All

39 bioactivities documented in the literature are reported, therefore including studies for

40 which pure active substances were described, as well as studies limited to extracts or

41 fractions. From the early 1980s until today, 49 scientific works have been published

42 on Lobophora chemistry and bioactivity, among which 40 have reported bioactivities.

43 Only six studies, however, have identified, characterized and tested no less than 23

44 bioactive pure compounds (three $\mathrm{C}_{21}$ polyunsaturated alcohols, three fatty-acids, a

45 macrolactone, 11 polyketides, a few sulfated polysaccharides, three sulfolipids, a

46 tocopherol derivative). The present review intends to raise awareness of chemists and

47 biologists given the recent significant taxonomic progress of this brown algal genus,

48 which holds a promising plethora of natural products yet to be discovered with

49 ecological and pharmacological properties.

50

51 Keywords Bioactivity $\cdot$ Brown algae $\cdot$ Lobophora $\cdot$ Natural products 


\section{Abbreviations}

$54 \mathrm{ACVr}$

$55 \quad \mathrm{EC}_{50}$

56 HCT-116

57 HEp-2

58 HIV

59 HL-60

$60 \mathrm{HSV}-1 / 2$

61 HT-29

$62 \quad \mathrm{IC}_{50}$

$63 \mathrm{LC}_{50}$

$64 \quad \mathrm{LD}_{50}$

65 MCF-7

66 MDCK

$67 \quad \mathrm{MIC}_{90}$

68

$69 \quad$ MZI

70 RSV

71 SQDG

72
Acyclovir-resistant

Half maximal Effective concentration

Human colon tumor

Human epithelial type 2

Human immunodeficiency virus

Human promyelocytic leukemia cell line

Herpes simplex virus type 1 or 2

Human colorectal adenocarcinoma cell line

Half maximal inhibitory concentration

Median lethal concentration

Median lethal dose

Human breast carcinoma cell line

Madin-Darby canine kidney

Minimal inhibitory concentration to inhibit the growth of $90 \%$

of organisms

Mean zone of inhibition

Respiratory syncytial virus

Sulfoquinovosyl diacylglycerol 
The brown marine algal genus Lobophora J. Agardh (Dictyotales, Phaeophyceae) is distributed worldwide in tropical to temperate waters and represents an important algal component in coral reef ecosystems (Vieira et al. 2014; Bennett et al. 2010; De Ruyter van Steveninck and Breeman 1987; Diaz-Pulido et al. 2009). Lobophora belongs to the Dictyotaceae, a family which has proven to be a particularly rich and diverse source of natural products and predominantly diterpenes (Maschek and Baker 2008; Vallim et al. 2005; Blunt et al. 2015). These natural products have been particularly studied for their bioactivity for human health but also for their putative ecological role in nature. The terpenoids isolated from the Dictyotaceae exhibit various types of bioactivity such as feeding deterrence, antifungal, cytotoxic, antibiotic, anti-inflammatory, insecticidal or antiviral activities. However, while some genera have received much attention, notably Dictyota and Dictyopteris (Hay and Steinberg 1992; Paul et al. 2006; Paul and Ritson-Williams 2008), others like Lobophora raised less interest and a very limited number of natural products have already been described from algae of this genus. This limited attention may be explained by the taxonomic deficiency this genus has suffered from until recently. Indeed, only three Lobophora species were recognized until the end of the last century, with Lobophora variegata (Lamouroux) Womersley ex Oliveira being by far the most commonly reported species, apparently distributed in the world's oceans. This species has been cited in virtually all the chemical studies conducted on the genus Lobophora (Table 1). However, recent DNA-based studies (Sun et al. 2012; Vieira et al. 2014) have shed new light on Lobophora taxonomy. Today, 20 species are taxonomically accepted (Guiry and Guiry 2015) and 80 more have been estimated (Vieira 2015). The high genetic diversity recently unveiled within this genus presupposes that a richer chemodiversity is yet to be discovered. This review aims to report the state-of-the-art of the natural products isolated from Lobophora species (Dictyotales, Phaeophyceae) and their associated bioactivities. All bioactivities documented in the literature are reported in Table 1, therefore including studies for which pure active substances were described, as well as studies limited to extracts

104 been reported are presented in Table 2. Lobophora bioactive natural products reported 105 here are presented in Figure 1. 
106 Note that the recent taxonomic progress of the genus Lobophora naturally questions 107 the validity of what has been nearly always reported as L. variegata based on external 108 morphological criteria. Therefore, although referred to in the literature as L. variegata 109 or in only one instance as L. papenfussii, we will presently simply make reference to 110 the genus Lobophora.

111 Relevant literature was searched with the databases Marinlit, Google Scholar, ISI 112 Web of Science, JSTOR and PubMed. A targeted search of English literature (i.e. 113 papers with minimum an English title and abstract) was conducted using the key word

114 'Lobophora' followed by the search terms [activity or allelopath* or anti* or 115 bioactiv* or chemi* or extract or metabolite or natural product]. An asterisk $\left(^{*}\right)$ is a 116 wildcard character that means "any character", which allows the database or search 117 engine to look for multiple words that have different endings, e.g. bioactiv* captures 118 [bioactive AND bioactivity].

119 Antimicrobial activities

120 Antimicrobial (anti-bacterial, -viral, -fungal or -protozoal) activities of extracts, 121 fractions or compounds isolated from Lobophora species have been by far the most 122 explored type of bioactivities searched for this genus. Like other eukaryotes, 123 macroalgae harbor a large and diverse microbial community, which play important 124 roles for the host (Egan et al. 2013). The selection of associated or symbiotic bacteria 125 may be related to the production of specialized metabolites that play important 126 functions against harmful marine microorganisms (Egan et al. 2013) as well as against 127 some human pathogens.

128 Antibacterial activities

129 Organic extracts of Lobophora species have shown a broad-spectrum of antibacterial 130 activities (Morrow et al. 2011; Engel et al. 2006; Manilal et al. 2012; Manilal et al. 131 2010a; Gutiérrez-Cepeda et al. 2015; Manilal et al. 2010b; Ballantine et al. 1987; 132 Sivakumar 2014). Engel et al. (2006) considered two morphotypes of Lobophora, 133 crustose and ruffled, which we strongly suspect to be two distinct species. Lipophilic 134 and hydrophilic parts of organic extracts from both morphotypes resulted in growth 135 inhibition of the bacteria Pseudoalteromonas bacteriolytica. However, the two 136 morphotypes extracts yielded contrasting $\mathrm{IC}_{50}$ values: the lipophilic parts showed 
137 volumetric $\mathrm{IC}_{50 \mathrm{~s}}$ of 1 and 0.24 (unitless) for the crustose and ruffled types, 138 respectively, and the hydrophilic parts exhibited volumetric $\mathrm{IC}_{50 \text { s }}$ of 0.51 and 0.67 , 139 respectively. It would therefore appear that these two different morphotypes have 140 contrasting chemical production.

141 The chloroform-methanolic extract of Caribbean Lobophora presented antibacterial 142 activity against Bacillus subtilus (Ballantine et al. 1987). The organic extract of 143 Lobophora samples from India showed a strong inhibition against Salmonella typhi 144 and Vibrio cholera while being less active against Klebsilla pneumonia and E.coli 145 (Sivakumar 2014). Val et al. (2001) did not observed any antimicrobial activity of the 146 methanolic extract of Lobophora harvested in Canary Islands (Spain) against a panel 147 of pathogen bacterial strains. Manilal et al. (2010a), Manilal et al. (2010b) and 148 Manilal et al. (2012) showed that Lobophora methanolic extract exhibited a strong 149 antibacterial activity against a wide array of bacteria including the biofilm-forming 150 bacteria Vibrio sp., Colwellia sp. SW125 and Pseudoalteromonas bacteriolytica; the 151 pathogenic bacterial strains Aeromonas hydrophila, Bacillus cereus, Escherichia coli, 152 Micrococcus luteus and Salmonella typhimurium; the multiresistant human pathogens 153 B. subtilis, Pseudomonas aeruginosa, Staphylococcus aureus, S. epidermidis; and the 154 shrimp pathogens Vibrio parahaemolyticus, V. vulnificus, V. harveyi, V. alcaligenes 155 and $V$. alginolyticus. Manilal et al. (2012) characterized by gas chromatography seven 156 fatty acids (palmitic, lauric, stearic, $\alpha$-linolenic, oleic, myristic and hexadecatrienoic 157 acids) from an active Lobophora fraction, thus suggesting that the antibacterial 158 bioactivity could be attributed to the synergistic effects of these compounds. In fact, 159 fatty acids, such as oleic, lauric and palmitic acids have already demonstrated 160 antibacterial activity (Kabara et al. 1972). But while lauric and myristic acids 161 presented inhibitory effect on the 11 bacterial strains tested by the authors, the effect 162 of oleic acid was restricted to only one strain (Streptococcus group A) (Kabara et al. 163 1972). Morrow et al. (2011) showed that Lobophora organic extract induced a shift in 164 the assemblage of bacteria associated to corals. Gerwick Fenical (1982) tested the in 165 vitro antibacterial activity of a new aromatic polyketide identified from this species, 166 1-(2,4,6-trihydroxyphenyl)hexadecane-1-one (1), against a panel of six bacteria $(S$. 167 aureus, B. subtilis, E. coli, Enterobacter aerogenes, P. aeruginosa, Vibrio 168 anguillarum) but did not observe any effect. Similarly, Gutiérrez-Cepeda et al. (2015) 169 identified 10 new polyketides (13-22) and tested the antimicrobial effect of seven of 
them (13-15, 17-19 and 22) against Enterococcus faecalis, E. coli, and S. aureus. The authors showed that the compounds $\mathbf{1 3}$ and $\mathbf{1 4}$ inhibited the growth of $S$. aureus by $100 \pm 1 \%$ (average $\pm \mathrm{SD}$ ) and $65 \pm 2 \%$, respectively at $100 \mu \mathrm{g} \mathrm{ml}-1$ concentration. The minimum inhibitory concentration $\left(\mathrm{MIC}_{90}\right)$ of lobophorol A (13) against $S$. aureus was shown to be $25 \mu \mathrm{g} \mathrm{ml}-1$.

\section{Antiviral activities}

Lobophora aqueous extracts presented interesting bioactivities against a wide range of viruses. Some polysaccharides isolated from Lobophora exhibited antiviral activities against the herpes simplex virus types 1 and $2\left(\mathrm{EC}_{50} 18.2\right.$ and $6.25 \mu \mathrm{g} \mathrm{ml}-1$, respectively), and a very low cytotoxicity to Vero, HEp-2, and MDCK cell lines as well as a moderate activity against respiratory syncytial virus (RSV) (Wang et al. 2008a). Lobophora aqueous extract exhibited anti-HSV properties $\left(\mathrm{EC}_{50} 18.5\right.$ and $9 \mu \mathrm{g} \mathrm{ml-1}$ for HSV-1 and HSV-2, respectively) and a moderate anti-RSV activity (Wang et al. 2008b). The organic extract strongly inhibited HSV-1-ACVr (92\% of inhibition) but did not inhibit at all HSV-2-ACVr (Soares et al. 2012). Queiroz et al. (2008) showed that a sulfated polysaccharide isolated from Lobophora (a galactofucan of $1400 \mathrm{kDa}$, with fucose, galactose, glucose and sulfate at molar ratio of 1:2:3:0.5), exhibited antiretroviral effect by inhibiting reverse transcriptase activity of human immunodeficiency virus. Kremb et al. (2014) showed that Lobophora aqueous extracts also inhibited HIV-1 infection at the level of virus entry into cells.

Antifungal activities

Some Lobophora extracts showed antifungal activities against a broad spectrum of fungi. The lipophilic part of an organic extract of the crustose type induced $100 \%$ growth inhibition of Dendryphiella salina (ascomycete) and the fungi-like Halophytophthora spinosa (oomycete), but no effect on Lindra thalassiae (ascomycete). On the other hand, the lipophilic extract of the ruffled type did not inhibit the growth of any of the three tested fungi. The hydrophilic extracts of both Lobophora types resulted in the growth inhibition by ca. $70 \%$ of only the oomycete $H$. spinosa. We notice here again that the different morphotypes of Lobophora have contrasting bioactivities against different micro-organisms (Engel et al., 2006). Gerwick Fenical (1982) tested the antifungal activity of the polyketide (1) against 
201 Candida albicans, a causal agent of opportunistic oral and genital infections in 202 humans, but did not observe any effect. Some Lobophora organic extracts also failed 203 to inhibit the growth of Aspergillus fumigatus, C. albicans and Saccharomyces 204 cerevisiae (Val et al., 2001). Kubanek et al. (2003) identified a macrolactone 205 polyketide named lobophorolide (2), which exhibited sub-micromolar activity against 206 pathogenic and saprophytic marine fungi (Dendryphiella salina, Lindra thalassiae 207 and $C$. albicans) with $\mathrm{IC}_{50}$ values ranging from 0.034 to $1.3 \mu \mathrm{g} \mathrm{ml}-1$. Lobophorolide 208 is structurally related to tolytoxin, scytophycins, and swinholides, macrolides 209 previously isolated from terrestrial cyanobacteria, marine sponges and gastropods 210 (Kubanek et al. 2003). These structural similarities raise the question of its origin, and 211 the authors suggested that the molecule is more probably biosynthesized by 212 Lobophora associated-bacteria.

\section{Antiprotozoal activities}

214 Lobophora extracts presented antiprotozoal activities against six protozoan parasites, 215 namely Trichomonas vaginalis (a common and worldwide parasite which infects the 216 urogenital tract of men and women), Entamoeba histolytica (parasite infecting 217 humans and other primates), Giardia intestinalis (responsible for enteric protozoan 218 infections), Schizochytrium aggregatum (marine protist), Leishmania mexicana (one 219 of the causative species of leishmaniasis) and Trypanosoma cruzi (causative species 220 of trypanomiasis). The organic extract exhibited anti-trichomonal activity with an $\mathrm{IC}_{50}$ 221 of $1.39 \mu \mathrm{g} \mathrm{ml}-1$ (Moo-Puc et al. 2008), an $\mathrm{IC}_{50}$ of $3.2 \mu \mathrm{g}$ ml-1 against Trichomonas 222 vaginalis (Cantillo-Ciau et al. 2010), and anti-leishmanial in vitro properties against 223 Leishmania mexicana promastigote forms with a $\mathrm{LC}_{50}$ value of $49.9 \mu \mathrm{g} \mathrm{ml}-1$ (Freile-

224 Pelegrin et al. 2008). The same extract exhibited a moderate in vitro antiprotozoal 225 activity against Trypanosoma cruzi with an $\mathrm{IC}_{50}$ of $9.72 \mu \mathrm{g}$ ml-1 (León-Deniz et al. 226 2009). Cantillo-Ciau et al. (2010) identified three sulfoquinovosyldiacylglycerols

227 (SQDGs;

228 quinovopyranosyl)glycerol 1-O-palmitoyl-2-O-myristoyl-3-O-(6"'-sulfo- $\alpha-D$ (3), 1,2-di- $O$-palmitoyl-3- $O$-(6"'-sulfo- $\alpha-D$ quinovopyranosyl)glycerol (4) and 1-O-palmitoyl-2-O-oleoyl-3-O-(6"'-sulfo- $\alpha-D$ quinovopyranosyl)glycerol (5) with antiprotozoal activity from a lipophilic fraction. SQDGs were shown to exhibit an in vitro antiprotozoal activity against Entamoeba histolytica with an $\mathrm{IC}_{50}$ of $3.9 \mu \mathrm{g} \mathrm{ml}-1$, and a moderate activity against $T$. vaginalis 
233 trophozoites with an $\mathrm{IC}_{50}$ of $8 \mu \mathrm{g}$ ml-1. Engel et al. (2006) observed differences in the 234 antiprotozoal activities of both Lobophora types presented earlier. While both 235 hydrophilic and lipophilic parts of the organic extract of the crustose type inhibited 236 the growth of Schizochytrium aggregatum, only the lipophilic part of the ruffled type 237 showed a significant inhibition (Engel et al. 2006).

\section{Additional pharmacological bioactivities}

239 In addition to the antimicrobial activities presented above, Lobophora presented 240 several additional bioactivities with some pharmacological potential, including anti241 angiogenic, anticoagulant, anti-inflammatory antioxidant, cytotoxic (including 242 antitumoral) and hemagglutinating activities. Lobophora extracts and sulfated 243 polysaccharides were shown to exhibit anticoagulant (De Lara-Isassi et al. 2004; 244 Medeiros et al. 2008; Castro et al. 2014b), antioxidant (Zubia et al. 2007; Paiva et al. 245 2011; Castro et al. 2014b; Sathyaseelan et al. 2015), anti-inflammatory (Paiva et al. 246 2011; Siqueira et al. 2011; Medeiros et al. 2008; Castro et al. 2014b), 247 hemagglutinating (Lima Ainouz et al. 1992) as well as anti-angiogenic (Castro et al.

248 2014a) activities. Lobophora aqueous extract demonstrated low cytotoxic properties 249 on human breast carcinoma MCF-7 cell lines, at a concentration of $200 \mu \mathrm{g} \mathrm{ml}$ 250 1(Wang et al. 2008b), and against the human nasopharyngeal carcinoma (KB) cell 251 line (Moo-Puc et al. 2009). Semi-purified fractions of Lobophora also exhibited 252 potential cytotoxic activity on a cultured human melanoma cancer cell line (Rocha et 253 al. 2007). Lobophorolide (2) also showed antineoplastic activity ( $\left.\mathrm{IC}_{50} 0.03 \mu \mathrm{g} \mathrm{ml}-1\right)$ 254 on the human colon tumor cell line HCT-116 (Kubanek et al. 2003), and sulfated 255 polyscaccharides presented anti-tumoral effects on human colon adenocarcinoma cell 256 line HT-29 (Castro et al. 2014b). Several organic Lobophora extracts were active

257 against P-388 lymphocytic leukemia and Ehrlich ascites tumor in mice (Kashiwagi et 258 al. 1980). Queiroz et al. (2006) showed a cytotoxic action of Lobophora 259 polysaccharides (a glucan and three galactofucans) on HL60 cells. The molecular 260 mechanism of the cytotoxic effect of these polymers has not been clearly defined but 261 this study suggested a possible involvement of phosphatases.

\section{Pesticidal activities}


263 Two studies assessed the pesticidal activities (i.e. pupicidal, nematicidal and 264 phytotoxic activities) of Lobophora (Manilal et al. 2012; Bianco et al. 2013). 265 Lobophora showed a larvicidal potential against the dengue mosquito Aedes aegypti 266 (52 $\pm 2.9 \%$ larval mortality at $500 \mathrm{ppm}$ concentration; Bianco et al. 2013), and 267 pupicidal potential against the urban mosquito Culex quinquefasciatus with a $\mathrm{LD}_{50}$ 268 value of $683 \mu \mathrm{g} \mathrm{ml-1} \mathrm{(Manilal} \mathrm{et} \mathrm{al.} \mathrm{2012).} \mathrm{Lobophora} \mathrm{methanolic} \mathrm{extract} \mathrm{presented} \mathrm{a}$ 269 nematicidal activity against the plant-pathogenic nematode Meloidogyne javanica 270 with a $\mathrm{LD}_{50}$ value of $1.16 \mathrm{mg} \mathrm{ml-1}$; and a phytotoxic activities against several plant 271 seeds (Cicer arietinum, Vigna radiate and Cajanus cajan), with a no growth response 272 of C. cajan, V. radiate and C. arietinum at a seaweed extract concentration of 4, 6 and $2738 \mathrm{mg} \mathrm{ml}-1$, respectively (Manilal et al. 2012). Manilal et al. (2012) have attributed 274 these pesticidal activities to a synergistic effect between the fatty acids they have 275 identified (see above).

\section{Bromophenols production}

277 Lobophora have been shown to produce bromophenols, a group of key flavor 278 compounds in seafood. Chung et al. (2003) found four bromophenols in Lobophora 279 namely 4-bromophenol (9), 2,4-dibromophenol (10), 2,6-dibromophenol (11), and 280 2,4,6-tribromophenol (12). These authors also showed that comparatively to two other 281 brown algae, Padina arborescens and Sargassum siliquastrum, Lobophora presented 282 the highest amount of bromophenols. Bromophenols have demonstrated a variety of 283 biological activities including antioxidant, antimicrobial, anticancer, anti-diabetic, and 284 anti-thrombotic effects (Liu et al. 2011). Nevertheless, to our knowledge no study has 285 yet shown bioactivities for any of the four bromophenols isolated from Lobophora. 286 Chkhikvishvili Ramazanov (2000) reported that the total phenolic substances content in Lobophora represent $1.2 \%$ of dry weight.

\section{Edibility, nutritional and nutraceutical values}

289 Widely consumed in some Asian countries (Zaneveld 1959), marine algae are well290 known as a functional food for their richness in carotenoids, dietary fibers, essential 291 fatty acids, lipids, minerals, polysaccharides, proteins and vitamins (Holdt and Kraan 292 2011; Plaza et al. 2008; Ito and Hori 1989; Dawczynski et al. 2007; Burtin 2003). 293 However, only a handful of studies have been interested in testing the edibility and 
nutritional value of Lobophora. Gerwick Fenical (1982) isolated one form of vitamin E ( $\gamma$-tocopherol (6)) from Lobophora, which has distinct properties from the more common $\alpha$-tocopherol (Jiang et al. 2001), the form of vitamin $\mathrm{E}$ that is preferentially absorbed an accumulated in humans (Rigotti 2007). Sousa et al. (2008) measured the content in $\beta$-carotene, retinol equivalent (vitamin A) and $\gamma$-tocopherol in Lobophora: $4.185 \pm 1.559 \mu \mathrm{gg}$-1 fresh weight of $\beta$-carotene, $0.697 \pm 0.260 \mu \mathrm{gg}$-1 of retinol equivalent and $4.722 \pm 2.062 \mu \mathrm{g}$ g-1 of $\gamma$-tocopherol. Lobophora presented the lowest $\gamma$-tocopherol concentration amongst other Phaeophyceae (i.e. Dictyopteris delicatula, Dictyota dichotoma, Padina gymnospora and Sargassum cymosum). Hegazi (2002) analyzed the pigment composition of Lobophora from the Red Sea and fourteen compounds were reported: chlorophylls a, a', $\mathrm{c}_{1}$ and $\mathrm{c}_{2}$, fucoxanthin, violaxanthin, flavoxanthin, fucoxanthol, antheraxanthin, 9-cis-neoxanthin, diatoxanthin, zeaxanthin, $\beta$-carotene and phaeophytin a. fucoxanthin, flavoxanthin, diatoxanthin and zeaxanthin are typical xanthophylls of Chromophyta, while chlorophyll $\mathrm{c}_{1}$ and chlorophyll $\mathrm{c}_{2}$ are the characteristic chlorophylls of this algal group. In Lobophora chlorophyll a is the most important (0.27 mg g-1), followed by chlorophylls $c_{1}$ and $c_{2}(0.001 \mathrm{mg}$ g-1 each). Among the carotenoids, fucoxanthin was the dominant pigment (0.12 mg g-1), followed by $\beta$-carotene (0.06 $\mathrm{mg}$ g-1) and violaxanthin (0.04 mg g-1). Carotenoids such as fucoxanthin, $\beta$-carotene and violaxanthin have demonstrated the ability to act as antioxidants, and to prevent the development of different degenerative diseases and health conditions in humans, including age-related macular degeneration, cataract, certain cancers, rheumatoid arthritis, muscular dystrophy and cardiovascular problems (Kim and Pangestuti 2011; Ibañez and Cifuentes 2013; Ahmed et al. 2013). Thennarasan (2015) analyzed the biochemistry of Lobophora, i.e. the composition in fatty acids, minerals, sterols, total carbohydrates, total lipids, total proteins and vitamins (Table 2). Results of this study showed that Lobophora presents a high content of total protein $(23.13 \pm 0.05 \%$ of total content $)$ and total carbohydrate $(19.34 \pm 0.10 \%)$, and a low content of total lipid $(0.27 \pm 0.5 \%)$. While Lobophora has a high fatty acid to total lipid ratio (58\%), it has a low total lipid content ( $<50 \mathrm{mg}$ g-1

324 Dictyota dichotoma, and Spatoglossum macrodontum; total lipid content >100 mg g-1 325 dry weight) (Gosch et al. 2012). Lobophora is also rich in vitamins (especially

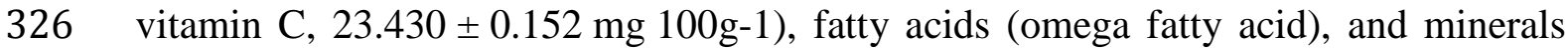




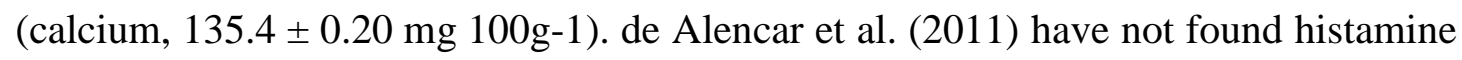
and tyramine, amines that can cause intoxication symptoms, in quantities high enough to cause pharmacological actions in Lobophora. Lobophora appears to be a source of carbonyl compounds (e.g. aldehydes and ketones) (Mota da Silva et al. 2006). While many aldehydes and ketones are used as food flavorings (e.g. propanal, propanone) and preservatives (e.g. formaldehyde), some aldehydes can also act as mutagens and carcinogens (Leikauf 1992; Goldschmidt 1984). For instance, formaldehyde is classified as a "probable human carcinogen" (Thrasher and Kilburn 2001), and acetaldehyde can induce nasal carcinomas (Miyake and Shibamoto 1995).

\section{Ecological roles}

337 Fewer are the studies targeted towards understanding the ecological roles of 338 Lobophora metabolites. Three main ecological roles have been investigated, namely 339 antifouling, feeding deterrence, and effects on benthic competitors.

$340 \quad$ Antifouling

341 As an evolutionary response to the ecological disadvantages of epibiosis, most if not 342 all macroalgae have developed antifouling chemical defenses. However, these 343 antifouling defenses are not equally efficient across different algal taxa, and some 344 may harbor a significant community of epiphytes. Such is the case of Lobophora, 345 which blades act as an important living substratum (Fricke et al. 2011). Yet, the upper-side blade surface is generally less epiphytized than the underside surface. Two studies have been performed to assess the antifouling properties of compounds produced by Lobophora against mussels, barnacles and bacterial biofilm (Manilal et

349 al. 2010a; Da Gama et al. 2008). The methanolic extracts showed considerable 350 antifouling activity against biofilm forming bacteria, i.e. Vibrio sp. $(11 \pm 2.5 \mathrm{~mm}$ zone 351 of inhibition (MZI)), Colwellia sp. SW125 (6 $2.1 \mathrm{~mm} \mathrm{MZI)} \mathrm{and} \mathrm{Pseudoalteromonas}$ 352 sp. SW124 (9 $\pm 1.5 \mathrm{~mm}$ MZI) (Manilal et al. 2010a). On the other hand, some

353 Lobophora extract stimulated the attachment to the algal surface of the brown mussel 354 Perna perna, and apparently did not show significant activity against the barnacle 355 Balanus amphitrite and mussel Mytilus edulis attachment (data not presented; Manilal 356 et al. 2010a). Although not clearly demonstrated, antifouling activities might be 
attributable to phlorotannins, a class of molecules present in Lobophora, that have been reported to present antifouling activity (Amsler and Fairhead 2005).

359 Effects on benthic competitors

360 As a consequence of natural or anthropogenic perturbations of their environmental 361 conditions, some coral reefs have shifted from a coral- to a macroalgal-dominance. 362 Lobophora has been reported in such events and allelopathy has been suggested as a 363 possible mechanism allowing the alga to outcompete corals in damaged reefs by 364 causing bleaching and suppressing photosynthetic efficiency. Some authors (e.g. 365 Longo and Hay 2014; Vieira et al. 2015; Antonius and Ballesteros 1998) observed 366 that Lobophora contacting some corals (e.g. Agaricia, Porites, Seriatopora) was 367 associated with more or less important bleaching. While an allelopathic mechanism 368 has been suggested in the late 1990s (Antonius and Ballesteros 1998), it has only 369 recently been experimentally tested (Rasher and Hay 2010b; Slattery and Lesser 370 2014; Vieira et al. in revision). Those latter studies clearly demonstrated that 371 Lobophora possesses potentially adverse chemicals to several corals (Porites 372 cylindrica, Porites porites, Montastrea cavernosa, Acropora muricata, Stylophora 373 pistillata and Montipora hirsuta), although their actual efficiency in situ remains to be 374 proven (Vieira et al. in revision). Slattery Lesser (2014) and Vieira et al. (in revision) 375 identified four molecules with bleaching properties: SQDG (3) identified by Cantillo376 Ciau et al. (2010) (Slattery and Lesser 2014), and three new $\mathrm{C}_{21}$ polyunsaturated 377 alcohols (6-8) (Vieira et al. in revision). Slattery Lesser (2014) experimentally 378 showed that $\mathbf{3}$ presented bleaching activity against the coral M. cavernosa, and Vieira 379 et al. (in revision) showed that the all lobophorenols (6-8) exhibited bleaching 380 activities against the coral $A$. muricata. In Vieira et al. (in revision) a significant 381 number of semi-purified fractions also exhibited a more or less significant activity 382 against corals.

383 Lobophora natural compounds adversity towards corals may be indirect, by affecting 384 the coral-associated bacterial community and notably by causing community shifts on 385 Montastraea faveolata and Porites astreoides colonies (Morrow et al. 2012), and also 386 causing a sublethal stress. No compounds with such effects have yet been identified, 387 but only the aqueous extract has been found to show ecological effects.

388 Effects on coral larval recruitment 
Lobophora has contrasting effects on coral larval recruitment. Birrell et al. (2008) showed that Lobophora is able to enhance larvae settlement of Acropora millepora by $40 \%$. On the contrary, Kuffner et al. (2006) showed that Lobophora causes either recruitment inhibition or avoidance behavior in $P$. astreoides larvae. Diaz-Pulido et al.

393 (2010) also showed that Lobophora presented either no effect on 2-days-old larvae or 394 inhibitory effects on settlement of coral larvae. Similarly, Baird Morse (2004) showed 395 that Lobophora inhibited metamorphosis in coral larvae. Morse et al. (1996) found 396 that larvae of several Acroporids species did not settle in assays that included 397 Lobophora plants. Nevertheless, no compound, either acting as enhancers or 398 inhibitors, has already been identified.

399 Deterrence function

400 Lobophora has been the subject of contradictory observations in terms of 401 susceptibility to herbivory. For example, while De Lara-Isassi et al. (2000) showed 402 ichthyotoxicity (from ethanol and acetone extracts) against the goldfish Carassius 403 auratus, Slattery Lesser (2014) concluded that Lobophora chemical defenses 404 (Lobophora crude extract and a purified SQDG) were inactive against the omnivorous 405 pufferfish (Canthigaster rostrata). The experiment of De Lara-Isassi et al. (2000), 406 which aimed at testing the ichthyotoxicity of phlorotannins, is nonetheless 407 ecologically poorly relevant since the goldfish is a freshwater fish. Lobophora feeding 408 deterrence potential was suggested based on the presence of phlorotannins and 409 terpenes (Targett and Arnold 1998; Amsler and Fairhead 2005), which may cause the 410 precipitation of proteins (Stern et al. 1996). Stern et al. (1996) isolated phlorotannins 411 from Lobophora and suggested several explanations for why the biological activity of 412 phlorotannins may vary as a function of the gut environment of marine herbivores. In 413 addition, Bolser Hay (1996) concluded that the greater consumption of temperate 414 (North Carolina) versus tropical (the Bahamas) Lobophora by the sea urchin Arbacia 415 punctulata was likely due to the higher concentrations of secondary metabolites such 416 as pholorotannins in Lobophora from the temperate regions than in tropical regions. 417 Weidner et al. (2004) showed that while Lobophora exhibited inducible defenses 418 following direct consumption by amphipods, the repulsive effects of the non-polar 419 extracts were overridden by counteracting effects of non-extracted chemicals, making 420 live plants more nutritive. Nevertheless, toxicity of Lobophora extracts towards fish 
421 has only been suggested, but not rigorously tested (De Lara-Isassi et al. 2000).

422 Cetrulo Hay (2000) investigated the activation of chemical defenses in 42 species of

423 seaweeds including Lobophora, but the latter, together with other Dictyotacean

424 species, failed to show activation following damage by the spottail finfish Diplodus

425 holbrooki, and the sea urchin Lytechinus variegatus.

\section{Conclusion and prospects}

427 The chemical content and associated bioactivities of Lobophora species started to be 428 explored in the early 1980s. Lobophora exhibits a wide array of bioactivities such as 429 pharmacological (e.g. antibacterial, antiviral, antioxidant, antitumoral), pesticidal, and 430 ecological. The limited number of studies conducted on the subject showed that this 431 alga is a promising functional food.

432 Most studies were performed with extracts and mainly focused on their 433 pharmacological potential, whereas only few chemicals compounds have been 434 characterized. Only six studies have identified, characterized and tested no less than 43523 bioactive compounds (three $\mathrm{C}_{21}$ polyunsaturated alcohols, three fatty-acids, a 436 polyketide macrolactone, 11 polyketides, a few sulfated polysaccharides, three 437 sulfolipids, a tocopherol derivative). Additional chemical studies are urgently required 438 in order to fully characterize the compounds responsible for the large array of 439 biological activities encountered. Furthermore, recent major progress in the taxonomy 440 of this brown algal genus, suggests that a plethora of natural compounds is yet to be 441 discovered within the 110 estimated species (Vieira 2015).

442 This review is written in this pivotal moment in the chemical knowledge of 443 Lobophora, and aims at triggering the interest of chemists, biologists and 444 pharmacologists in exploring this mine of natural compounds still largely under445 explored.

\section{Compliance with ethical standards}

448 Conflicts of interest The authors state no conflict of interest and have received no 449 payment for the preparation of this manuscript. 
451 Table 1. Lobophora natural products and associated bioactivities.

\begin{tabular}{|c|c|c|c|c|c|}
\hline Bioactivity & Species & Biological target & Molecule & Type of extract & Reference \\
\hline \multicolumn{6}{|c|}{ Antimicrobial activities } \\
\hline Antibacterial & L. variegata & $\begin{array}{l}\text { Enterococcus faecalis, Escherichia } \\
\text { coli, Staphylococcus aureus }\end{array}$ & $\begin{array}{l}\text { Lobophorols A-C, } \\
\text { lobophopyranones A and B, } \\
\text { lobophorones A-E }\end{array}$ & - & Gutiérrez-Cepeda et al. (2015) \\
\hline Antibacterial & L. variegata & $\begin{array}{l}\text { Escherichia coli, Salmonella typhi, } \\
\text { Klebsiella pneumonia, Vibrio cholera }\end{array}$ & - & $\mathrm{CHCl}_{3} / \mathrm{MeOH}$ & Sivakumar (2014) \\
\hline Antibacterial & L. variegata & $\begin{array}{l}\text { Bacillus cereus, Micrococcus luteus, } \\
\text { Salmonella typhimurium, Aeromonas } \\
\text { hydrophila, Escherichia coli }\end{array}$ & Mixture of fatty acids & $\mathrm{MeOH}$ & Manilal et al. (2012) \\
\hline Antibacterial & L. variegata & $\begin{array}{l}\text { Marine bacteria isolated from } \\
\text { Caribbean macroalgae and corals }\end{array}$ & - & $\begin{array}{l}\mathrm{EtOAc} / \mathrm{MeOH} \text { and then } \\
\mathrm{MeOH} / \mathrm{H}_{2} \mathrm{O}\end{array}$ & Morrow et al. (2011) \\
\hline Antibacterial & L. variegata & Biofilm-forming bacteria & - & $\mathrm{MeOH}$ & Manilal et al. (2010a) \\
\hline Antibacterial & L. variegata & $\begin{array}{l}\text { Vibrio parahaemolyticus, Vibrio } \\
\text { vulnificus, Vibrio harveyi, Vibrio } \\
\text { alcaligenes, Vibrio alginolyticus, } \\
\text { Staphylococcus aureus, Pseudomonas } \\
\text { aeruginosa, Bacillus subtilis, } \\
\text { Klebsiella pneumoniae, Staphylococcus } \\
\text { epidermidis }\end{array}$ & - & $\mathrm{MeOH}$ & Manilal et al. (2010b) \\
\hline Antibacterial & L. variegata & Pseudoalteromonas bacteriolytica & - & $\begin{array}{l}\mathrm{CH}_{2} \mathrm{Cl}_{2} / \mathrm{MeOH} \text { [divided into } \\
\text { lipophilic }(\mathrm{EtOAc}) \text { and } \\
\text { hydrophilic }\left(\mathrm{H}_{2} \mathrm{O}\right) \text { parts] }\end{array}$ & Engel et al. (2006) \\
\hline Antibacterial & L. variegata & $\begin{array}{l}\text { Bacillus subtilis, Enterococcus } \\
\text { faecium, Mycobacterium smegmatis, } \\
\text { Pseudomonas aeruginosa, Serratia } \\
\text { marcescens, Staphylococcus aureus }\end{array}$ & - & $\mathrm{MeOH}$ & Val et al. (2001) \\
\hline Antibacterial & L. variegata & $\begin{array}{l}\text { Bacillus subtilis, Pseudomonas } \\
\text { aeruginosa, Escherichia coli, } \\
\text { Staphylococcus aureus, Candida } \\
\text { albicans }\end{array}$ & - & $\mathrm{CHCl}_{3} / \mathrm{MeOH}$ & Ballantine et al. (1987) \\
\hline Antibacterial & L. papenfussii & $\begin{array}{l}\text { Staphylococcus aureus, Bacillus } \\
\text { subtilis, Escherichia coli, Enterobacter } \\
\text { aerogenes, Pseudomonas aeruginosa, } \\
\text { Candida albicans, Vibrio anguillarum }\end{array}$ & $\begin{array}{l}\text { 2-(1'-Oxohexadecyl)-1,3,5- } \\
\text { trihydroxybenzene }\end{array}$ & - & Gerwick Fenical (1982) \\
\hline Antiviral & L. variegata & HIV & - & $\mathrm{H}_{2} \mathrm{O}$ & Kremb et al. (2014) \\
\hline Antiviral & L. variegata & HSV-1 & - & $\mathrm{CH}_{2} \mathrm{Cl}_{2} / \mathrm{MeOH}$ & Soares et al. (2012) \\
\hline Antiviral & L. variegata & HIV & $\begin{array}{l}\text { Polysaccharide } \\
\text { (galactofucan) }\end{array}$ & & Queiroz et al. (2008) \\
\hline
\end{tabular}




\begin{tabular}{|c|c|c|c|c|c|}
\hline Antiviral & L. variegata & $\begin{array}{l}\text { Herpes simplex virus type } 1 \text { and } 2 \\
\text { (HSV-1 and -2), respiratory syncytial } \\
\text { virus (RSV) }\end{array}$ & & $\mathrm{H}_{2} \mathrm{O}$ & Wang et al. (2008b) \\
\hline Antifungal & L. variegata & $\begin{array}{l}\text { Dendryphiella salina, } \\
\text { Halophytophthora spinosa }\end{array}$ & - & $\begin{array}{l}\mathrm{CH}_{2} \mathrm{Cl}_{2} / \mathrm{MeOH} \text { [divided into } \\
\text { lipophilic }(\mathrm{EtOAc}) \text { and } \\
\text { hydrophilic }\left(\mathrm{H}_{2} \mathrm{O}\right) \text { parts] }\end{array}$ & Engel et al. (2006) \\
\hline Antifungal & L. variegata & $\begin{array}{l}\text { Dendryphiella salina, Lindra } \\
\text { thalassiae, Candida albicans }\end{array}$ & Lobophorolide & - & Kubanek et al. (2003) \\
\hline Antifungal & L. variegata & $\begin{array}{l}\text { Aspergillus fumigatus, Candida } \\
\text { albicans, Saccharomyces cerevisiae }\end{array}$ & - & $\mathrm{MeOH}$ & Val et al. (2001) \\
\hline Antiprotozoal & L. variegata & $\begin{array}{l}\text { Trichomonas vaginalis, Entamoeba } \\
\text { histolytica, Giardia intestinalis }\end{array}$ & $\begin{array}{l}\text { Mixture of sulfoquinovosyl- } \\
\text { diacylglycerols (SQDGs) }\end{array}$ & $\mathrm{CH}_{2} \mathrm{Cl}_{2} / \mathrm{MeOH}$ & Cantillo-Ciau et al. (2010) \\
\hline Antiprotozoal & L. variegata & Trypanosoma cruzi & - & $\mathrm{CH}_{2} \mathrm{Cl}_{2} / \mathrm{MeOH}$ & León-Deniz et al. (2009) \\
\hline Antiprotozoal & L. variegata & Trichomonas vaginalis & - & $\mathrm{CH}_{2} \mathrm{Cl}_{2} / \mathrm{MeOH}$ & Moo-Puc et al. (2008) \\
\hline Antiprotozoal & L. variegata & Leishmania mexicana & - & $\mathrm{CH}_{2} \mathrm{Cl}_{2} / \mathrm{MeOH}$ & Freile-Pelegrin et al. (2008) \\
\hline Antiprotozoal & L. variegata & Schizochytrium aggregatum & - & $\begin{array}{l}\mathrm{CH}_{2} \mathrm{Cl}_{2} / \mathrm{MeOH} \text { [divided into } \\
\text { lipophilic }(\mathrm{EtOAc}) \text { and } \\
\text { hydrophilic }\left(\mathrm{H}_{2} \mathrm{O}\right) \text { parts] }\end{array}$ & Engel et al. (2006) \\
\hline \multicolumn{6}{|c|}{ Other pharmacological activities } \\
\hline Anti-angiogenic & L. variegata & Embryonated chicken eggs & $\begin{array}{l}\text { Sulfated polysaccharides } \\
\text { (fucans) }\end{array}$ & - & Castro et al. (2014a) \\
\hline Anticoagulant & L. variegata & Human plasma & $\begin{array}{l}\text { Sulfated polysaccharides } \\
\text { (fucans) }\end{array}$ & - & Castro et al. (2014b) \\
\hline Anticoagulant & L. variegata & Human plasma & $\begin{array}{l}\text { Sulfated polysaccharide } \\
\text { (fucoidan) }\end{array}$ & - & Medeiros et al. (2008) \\
\hline Anticoagulant & L. variegata & Human plasma & - & $\mathrm{H}_{2} \mathrm{O}$ (Phosphate buffer) & De Lara-Isassi et al. (2004) \\
\hline Anti-inflammatory & L. variegata & Male Swiss-Webster mice & $\begin{array}{l}\text { Sulfated polysaccharides } \\
\text { (fucans) }\end{array}$ & - & Castro et al. (2014b) \\
\hline Anti-inflammatory & L. variegata & Wistar rats & $\begin{array}{l}\text { Sulfated polysaccharides } \\
\text { (fucans) }\end{array}$ & - & Paiva et al. (2011) \\
\hline Anti-inflammatory & L. variegata & Wistar rats & $\begin{array}{l}\text { Sulfated polysaccharide } \\
\text { (fucan) }\end{array}$ & - & Siqueira et al. (2011) \\
\hline Anti-inflammatory & L. variegata & Wistar rats & $\begin{array}{l}\text { Sulfated polysaccharide } \\
\text { (fucoidan) }\end{array}$ & - & Medeiros et al. (2008) \\
\hline Antioxidant & L. variegata & Chemical test & $\begin{array}{l}\text { 3-(2-methoxy-4-((2,5,6,8a- } \\
\text { tetramethyl-1,4,8,8a- } \\
\text { tetrahydronaphthalen-1- } \\
\text { yl)methyl)phenyl)propanoate }\end{array}$ & $\mathrm{H}_{2} \mathrm{O} / \mathrm{MeOH}$ & Sathyaseelan et al. (2015) \\
\hline Antioxidant & L. variegata & Wistar rats & - & - & Paiva et al. (2011) \\
\hline Antioxidant & L. variegata & Chemical test & - & $\mathrm{CH}_{2} \mathrm{Cl}_{2} / \mathrm{MeOH}$ & Zubia et al. (2007) \\
\hline
\end{tabular}




\begin{tabular}{|c|c|c|c|c|c|}
\hline Antioxidant & L. variegata & Chemical test & $\begin{array}{l}\text { Sulfated polysaccharides } \\
\text { (fucans) }\end{array}$ & - & Castro et al. (2014b) \\
\hline Cytotoxic & L. variegata & $\begin{array}{l}\text { Human nasopharyngeal carcinoma } \\
\text { (KB) cell line }\end{array}$ & - & $\mathrm{CH}_{2} \mathrm{Cl}_{2} / \mathrm{MeOH}$ & Moo-Puc et al. (2009) \\
\hline Cytotoxic & L. variegata & C32 human melanoma cells & - & Acetone and $\mathrm{H}_{2} \mathrm{O}$ & Rocha et al. (2007) \\
\hline Cytotoxic & L. variegata & $\begin{array}{l}\text { Human promyelocytic leukemia HL- } 60 \\
\text { cells }\end{array}$ & $\begin{array}{l}\text { Polysaccharides (a glucan and } \\
\text { three galactofucans) }\end{array}$ & - & Queiroz et al. (2006) \\
\hline Cytotoxic & L. variegata & Human colon tumor cell line HCT-116 & Lobophorolide & - & Kubanek et al. (2003) \\
\hline Cytotoxic & L. variegata & $\begin{array}{l}\text { Murine P-388 lymphocytic leukemia, } \\
\text { Ehrlich ascites tumor cells }\end{array}$ & - & $\begin{array}{l}n \text {-Hexane, } \mathrm{CHCl}_{3} \text { and then } \\
\text { ButOH }\end{array}$ & Kashiwagi et al. (1980) \\
\hline Cytotoxic & L. variegata & Vero, HEp-2 and MDCK cells & - & $\mathrm{H}_{2} \mathrm{O}$ & Wang et al. (2008a) \\
\hline Cytotoxic & L. variegata & Human breast carcinoma MCF-7 cells & - & $\mathrm{H}_{2} \mathrm{O}$ & Wang et al. (2008a) \\
\hline Cytotoxic & L. variegata & Human colon tumor cell line HT-29 & $\begin{array}{l}\text { Sulfated polysaccharides } \\
\text { (fucans) }\end{array}$ & - & Castro et al. (2014b) \\
\hline Hemagglutinating & L. variegata & $\begin{array}{l}\text { Chicken, goat, pig, rabbit and human } \\
\text { erythrocytes }\end{array}$ & - & $\mathrm{H}_{2} \mathrm{O}(\mathrm{NaCl})$ & Lima Ainouz et al. (1992) \\
\hline \multicolumn{6}{|l|}{ Pesticidal activities } \\
\hline Pupicidal & L. variegata & Culex quinquefasciatus & & & \\
\hline Nematicidal & L. variegata & Meloidogyne javanica & Fatty acids & $\mathrm{MeOH}$ & Manilal et al. (2012) \\
\hline Phytotoxic & L. variegata & $\begin{array}{l}\text { Cicer arietinum, Vigna radiate and } \\
\text { Cajanus cajan seeds }\end{array}$ & & & \\
\hline Larvicidal & L. variegata & Aedes aegypti & - & $\mathrm{CH}_{2} \mathrm{Cl}_{2} / \mathrm{MeOH}$ & Bianco et al. (2013) \\
\hline \multicolumn{6}{|l|}{ Ecological roles } \\
\hline Antifouling & L. variegata & Perna perna & - & $\mathrm{CH}_{2} \mathrm{Cl}_{2} / \mathrm{MeOH}$ or $\mathrm{CH}_{2} \mathrm{Cl}_{2}$ & Da Gama et al. (2008) \\
\hline Antifouling & L. variegata & $\begin{array}{l}\text { Balanus amphitrite, } \\
\text { Mytilus edulis }\end{array}$ & - & $\mathrm{MeOH}$ & Manilal et al. (2010a) \\
\hline Bleaching & L. variegata & Porites cylindrica & - & $\begin{array}{l}\mathrm{MeOH} \text { [Lipophilic (EtOAc) } \\
\text { part] }\end{array}$ & Rasher Hay (2010a) \\
\hline Bleaching & L. variegata & Montastrea cavernosa & SQDG & $\mathrm{CH}_{2} \mathrm{Cl}_{2} / \mathrm{MeOH}$ & Slattery Lesser (2014) \\
\hline Cell lysis & L. variegata & Agelas clathrodes & SQDG & $\mathrm{CH}_{2} \mathrm{Cl}_{2} / \mathrm{MeOH}$ & Slattery Lesser (2014) \\
\hline Ichtyotoxic & L. variegata & - & Phlorotannins & - & Stern et al. (1996) \\
\hline Ichtyotoxic & L. variegata & Carassius auratus & - & Acetone, $\mathrm{EtOH}$ and $\mathrm{H}_{2} \mathrm{O}$ & De Lara-Isassi et al. (2000) \\
\hline Ichtyotoxic & L. variegata & $\begin{array}{l}\text { Lytechinus variegatus, Diplodus } \\
\text { holbrooki }\end{array}$ & - & $\mathrm{CH}_{2} \mathrm{Cl}_{2} / \mathrm{MeOH}$ & Cetrulo Hay (2000) \\
\hline $\begin{array}{l}\text { Settlement } \\
\text { enhancement }\end{array}$ & L. variegata & Acropora millepora & - & Seawater (waterborne extract) & Birrell et al. (2008) \\
\hline
\end{tabular}


Shift of coral-

associated bacteria

Sublethal stress

Montastraea faveolata,

Porites astreoides

Montastraea faveolata

Porites astreoides
EtOAc/MeOH and then

$\mathrm{EtOH} / \mathrm{H}_{2} \mathrm{O}$

$\mathrm{EtOAc} / \mathrm{MeOH}$ and then

$\mathrm{EtOH} / \mathrm{H}_{2} \mathrm{O}$
Morrow et al. (2012)

Morrow et al. (2012) 
452 Table 2. Lobophora natural products for which bioactivity has not been tested in

453 the study.

\begin{tabular}{|c|c|c|}
\hline Molecule & Species & Reference \\
\hline \multicolumn{3}{|l|}{ Volatile carbonyl compounds } \\
\hline Acetaldehyde & Lobophora variegata & Mota da Silva et al. (2006) \\
\hline Butanal & $I d$. & Id. \\
\hline Formaldehyde & $I d$. & Id. \\
\hline Hexanal & $I d$. & Id. \\
\hline Pentanal & Id. & Id. \\
\hline Propanal & $I d$. & Id. \\
\hline Propanone & $I d$. & Id. \\
\hline \multicolumn{3}{|l|}{ Fatty acids } \\
\hline Docosahexaenoic acid (DHA) & Lobophora variegata & Thennarasan (2015) \\
\hline Eicosapentaenoic acid (EPA) & $I d$. & Id. \\
\hline Hexadecatrienoic acid & $I d$. & Manilal et al. (2012) \\
\hline Lauric acid & Id. & Id. \\
\hline Linoleic acid & $I d$. & Thennarasan (2015) \\
\hline Margaric acid & Id. & Id. \\
\hline Myristic acid & $I d$. & Manilal et al. (2012) \\
\hline Oleic acid & $I d$. & Thennarasan (2015), Manilal et al. (2012) \\
\hline Palmitic acid & Id. & Id. \\
\hline Stearic acid & $I d$. & Id. \\
\hline Stearidonic (moroctic) acid & $I d$. & Thennarasan (2015) \\
\hline$\alpha$-Linolenic acid & Id. & Thennarasan (2015), Manilal et al. (2012) \\
\hline \multicolumn{3}{|l|}{ Phenols } \\
\hline Phenolic substances & Lobophora variegata & Chkhikvishvili Ramazanov (2000) \\
\hline 4-Bromophenol & Lobophora sp. & Chung et al. (2003) \\
\hline 2,4,6-Tribromophenol & Id. & Id. \\
\hline 2,4-Dibromophenol & $I d$. & Id. \\
\hline 2,6-Dibromophenol & Id. & Id. \\
\hline Polyphenols & Lobophora variegata & (Rao and Untawale 1991) \\
\hline \multicolumn{3}{|l|}{ Photosynthetic pigment } \\
\hline 9'-Cis-Neoxanthin & Lobophora variegata & (Hegazi 2002) \\
\hline Antheraxanthin & $I d$. & Id. \\
\hline Chlorophyll $a$ & $I d$. & Id. \\
\hline Chlorophyll $a^{\prime}$ & Id. & Id. \\
\hline Chlorophyll c1 & $I d$. & Id. \\
\hline Chlorophyll c2 & $I d$. & Id. \\
\hline Diatoxanthin & Id. & Id. \\
\hline Flavoxanthin & $I d$. & Id. \\
\hline Fucoxanthin & $I d$. & Id. \\
\hline Fucoxanthol & $I d$. & Id. \\
\hline Phaeophytin $a$ & Id. & Id. \\
\hline Violaxanthin & $I d$. & Id. \\
\hline Zeaxanthin & $I d$. & Id. \\
\hline$\beta$-carotene & $I d$. & Sousa et al. (2008), (Hegazi 2002) \\
\hline \multicolumn{3}{|l|}{ Vitamins } \\
\hline Vitamin A & Lobophora variegata & Thennarasan (2015), Sousa et al. (2008) \\
\hline
\end{tabular}




\begin{tabular}{lll} 
Vitamin B1 & $I d$. & Thennarasan (2015) \\
Vitamin B2 & $I d$. & Id. \\
Vitamin B3 (niacinamide) & $I d$. & Id. \\
Vitamin B5 (calcium pantothenate) & $I d$. & Id. \\
Vitamin B6 & $I d$. & Id. \\
Vitamin B9 (folic acid) & $I d$. & Id. \\
Vitamin B12 & $I d$. & Id. \\
Vitamin C & $I d$. & Id. \\
Vitamin D & $I d$. & Id. \\
Vitamin E & $I d$. & Id. \\
$\gamma$-Tocopherol & Lobophora papenfussii, L. variegata & Gerwick Fenical (1982), Sousa et al. (2008) \\
\hline Sterols & & \\
\hline Campesterol & Lobophora variegata & Thennarasan (2015) \\
Stigmastanol (sitostanol) & $I d$. & Id. \\
$\beta$-sitosterol & Id. & Id. \\
\hline
\end{tabular}


Ahmed F, Fanning K, Schuhmann H, Netzel M, Schenk PM (2013) Microalgae: a valuable source of natural carotenoids with potential health benefits. In: Yamaguchi M (Ed.) Carotenoids: Food Sources, Production and Health Benefits. Nova Science Publishers, Hauppauge, NY, USA

Amsler CD, Fairhead VA (2005) Defensive and sensory chemical ecology of brown algae. Adv Bot Res 43:1-91

Antonius A, Ballesteros E (1998) Epizoism: a new threat to coral health in Caribbean reefs. Rev Biol Trop 46:145-56

Baird AH, Morse AN (2004) Induction of metamorphosis in larvae of the brooding corals Acropora palifera and Stylophora pistillata. Mar Freshwat Res 55:46972

Ballantine DL, Gerwick WH, Velez SM, Alexander E, Guevara P (1987) Antibiotic activity of lipid-soluble extracts from Caribbean marine algae. Hydrobiologia 151:463-69

Bennett S, Vergés A, Bellwood D (2010) Branching coral as a macroalgal refuge in a marginal coral reef system. Coral Reefs 29:471-80

Bianco EM, Pires L, Santos GK, Dutra KA, Reis TN, Vasconcelos ER, Cocentino AL, Navarro DM (2013) Larvicidal activity of seaweeds from northeastern Brazil and of a halogenated sesquiterpene against the dengue mosquito (Aedes aegypti). Ind Crop Prod 43:270-75

Birrell CL, McCook LJ, Willis BL, Harrington L (2008) Chemical effects of macroalgae on larval settlement of the broadcast spawning coral Acropora millepora. Mar Ecol Prog Ser 362:129-37

Blunt JW, Copp BR, Keyzers RA, Munro MH, Prinsep MR (2015) Marine natural products. Nat Prod Rep 32:116-211

Bolser RC, Hay ME (1996) Are tropical plants better defended? Palatability and defenses of temperate vs. tropical seaweeds. Ecology 77:2269-86

Burtin P (2003) Nutritional value of seaweeds. EJEAFChe 2:498-503

Cantillo-Ciau Z, Moo-Puc R, Quijano L, Freile-Pelegrín Y (2010) The tropical brown alga Lobophora variegata: A source of antiprotozoal compounds. Mar Drugs 8:1292-304

Castro LSEPW, de Sousa Pinheiro T, Castro AJG, Santos MdSN, Soriano EM, Leite EL (2014a) Potential anti-angiogenic, antiproliferative, antioxidant, and anticoagulant activity of anionic polysaccharides, fucans, extracted from brown algae Lobophora variegata. J Appl Phycol 27:1315-25

Castro LSEW, Pinheiro TS, Castro AJ, Dore CM, da Silva NB, Alves MGdCF, Santos MSN, Leite EL (2014b) Fucose-containing sulfated polysaccharides from brown macroalgae Lobophora variegata with antioxidant, anti-inflammatory, and antitumoral effects. J Appl Phycol 26:1783-90

Cetrulo GL, Hay ME (2000) Activated chemical defenses in tropical versus temperate seaweeds. Mar Ecol Prog Ser 207:243-53

Chkhikvishvili ID, Ramazanov ZM (2000) Phenolic substances of brown algae and their antioxidant activity. Appl Biochem Microbiol 36:289-91

Chung HY, Ma WCJ, Ang PO, Kim J-S, Chen F (2003) Seasonal variations of bromophenols in brown algae (Padina arborescens, Sargassum siliquastrum, and Lobophora variegata) collected in Hong Kong. J Agric Food Chem 51:2619-24

Da Gama BA, Carvalho AG, Weidner K, Soares AR, Coutinho R, Fleury BG, Teixeira VL, Pereira RC (2008) Antifouling activity of natural products from Brazilian seaweeds. Bot Mar 51:191-201

Dawczynski C, Schubert R, Jahreis G (2007) Amino acids, fatty acids, and dietary fibre in edible seaweed products. Food Chem 103:891-99 
de Alencar DB, Pires-Cavalcante KMS, de Sousa MB, Viana FA, Saker-Sampaio S (2011) Biogenic amines in marine macroalgae of the state of Ceará, Brazil. Rev Ciênc Agron 42:349

De Lara-Isassi G, Alvarez-Hernandez S, Collado-Vides L (2000) Ichtyotoxic activity of extracts from Mexican marine macroalgae. J Appl Phycol 12:45-52

De Lara-Isassi G, Alvarez-Hernández S, Quintana-Pimentel A (2004) Screening for anticoagulant substances in some marine macroalgae Detección de sustancias anticoagulantes en algunas macroalgas marinas. Hidrobiológica 14:47-54

De Ruyter van Steveninck E, Breeman A (1987) Deep water populations of Lobophora variegata (Phaeophyceae) on the coral reef of Curaçao: influence of grazing and dispersal on distribution patterns. Mar Ecol Prog Ser 38:24150

Diaz-Pulido G, Harii S, McCook L, Hoegh-Guldberg O (2010) The impact of benthic algae on the settlement of a reef-building coral. Coral Reefs 29:203-08

Diaz-Pulido G, McCook LJ, Dove S, Berkelmans R, Roff G, Kline DI, Weeks S, Evans RD, Williamson DH, Hoegh-Guldberg O (2009) Doom and boom on a resilient reef: climate change, algal overgrowth and coral recovery. PLoS One 4:e5239

Egan S, Harder T, Burke C, Steinberg P, Kjelleberg S, Thomas T (2013) The seaweed holobiont: understanding seaweed-bacteria interactions. FEMS Microbiol Rev 37:462-76

Engel S, Puglisi MP, Jensen PR, Fenical W (2006) Antimicrobial activities of extracts from tropical Atlantic marine plants against marine pathogens and saprophytes. Mar Biol 149:991-1002

Freile-Pelegrin Y, Robledo D, Chan-Bacab M, Ortega-Morales B (2008) Antileishmanial properties of tropical marine algae extracts. Fitoterapia 79:374-77

Fricke A, Titlyanova T, Nugues M, Bischof K (2011) Depth-related variation in epiphytic communities growing on the brown alga Lobophora variegata in a Caribbean coral reef. Coral Reefs 30:967-73

Gerwick W, Fenical W (1982) Phenolic lipids from related marine algae of the order Dictyotales. Phytochemistry 21:633-37

Goldschmidt BM (1984) Role of aldehydes in carcinogenesis. J Environ Sci Health C 2:231-49

Gosch BJ, Magnusson M, Paul NA, Nys R (2012) Total lipid and fatty acid composition of seaweeds for the selection of species for oil- based biofuel and bioproducts. Gcb Bioenergy 4:919-30

Guiry M, Guiry G (2015) AlgaeBase. World-wide electronic publication, National University of Ireland, Galway.

Gutiérrez-Cepeda A, Fernández JJ, Norte M, Montalvão S, Tammela P, Souto ML (2015) Acetate-derived metabolites from the brown alga Lobophora variegata. J Nat Prod 78:1716-22

Hay M, Steinberg P (1992) The chemical ecology of plant-herbivore interactions in marine versus terrestrial communities. In: Gerald A R May $R$ B Eds. Herbivores: their interactions with secondary plant metabolites.

Hegazi MM (2002) Separation, identification and quantification of photosynthetic pigments from three red sea seaweeds using reversed-phase highperformance liquid chromatography. Egypt $\mathrm{J}$ Bio 4:1-6

Holdt SL, Kraan S (2011) Bioactive compounds in seaweed: functional food applications and legislation. J Appl Phycol 23:543-97

Ibañez E, Cifuentes A (2013) Benefits of using algae as natural sources of functional ingredients. J Sci Food Agric 93:703-09

Ito K, Hori K (1989) Seaweed: chemical composition and potential food uses. Food Rev Int 5:101-44 
Jiang Q, Christen S, Shigenaga MK, Ames BN (2001) Y-Tocopherol, the major form of vitamin $E$ in the US diet, deserves more attention. Am J Clin Nutr 74:71422

Kabara JJ, Swieczkowski DM, Conley AJ, Truant JP (1972) Fatty acids and derivatives as antimicrobial agents. Antimicrob Agents Chemother 2:23-28

Kashiwagi M, Mynderse J, Moore R, Norton T (1980) Antineoplastic evaluation of Pacific basin marine algae. J Pharm Sci 69:735-38

Kim S-K, Pangestuti R (2011) Biological activities and potential health benefits of fucoxanthin derived from marine brown algae. Adv Food Nutr Res 64:111

Kremb S, Helfer M, Kraus B, Wolff H, Wild C, Schneider M, Voolstra CR, BrackWerner R (2014) Aqueous extracts of the marine brown alga Lobophora variegata inhibit HIV-1 infection at the level of virus entry into cells. PLoS One 9:e103895

Kubanek J, Jensen PR, Keifer PA, Sullards MC, Collins DO, Fenical W (2003) Seaweed resistance to microbial attack: a targeted chemical defense against marine fungi. Proc Natl Acad Sci U S A 100:6916-21

Kuffner IB, Walters LJ, Becerro MA, Paul VJ, Ritson-Williams R, Beach KS (2006) Inhibition of coral recruitment by macroalgae and cyanobacteria. Mar Ecol Prog Ser 323:107-17

Leikauf GD (1992) Formaldehyde and other aldehydes. Environmental toxicants: human exposures and their health effects, Third Edition:257-316

León-Deniz LV, Dumonteil E, Moo-Puc R, Freile-Pelegrin Y (2009) Antitrypanosomal in vitro activity of tropical marine algae extracts. Pharm Biol 47:864-71

Lima Ainouz I, Holanda Sampaio A, Barros Benevides N, Ponte Freitas A, Costa F, Carvalho M, Pinheiro-Joventino F (1992) Agglutination of enzyme treated erythrocytes by Brazilian marine algal extracts. Bot Mar 35:475-80

Liu M, Hansen PE, Lin X (2011) Bromophenols in marine algae and their bioactivities. Mar Drugs 9:1273-92

Longo G, Hay M (2014) Does seaweed-coral competition make seaweeds more palatable? Coral Reefs: $1-10$

Manilal A, Selvin J, Thajuddin N, Sujith S, Panikkar M, Idhayadhulla A, Kumar RS (2012) Biopotentials of marine alga, Lobophora variegata collected from the south Indian littoral. Thalassas 28:47-54

Manilal A, Sujith S, Sabarathnam B, Kiran GS, Selvin J, Shakir C, Lipton AP (2010a) Antifouling potentials of seaweeds collected from the southwest coast of India. World J Agric Sci 6:243-48

Manilal A, Sujith S, Selvin J, Seghal Kiran G, Shakir C, Premnath Lipton A (2010b) Antimicrobial potential of marine organisms collected from the southwest coast of India against multiresistant human and shrimp pathogens. Sci Mar (Barc) 74:287-96

Maschek JA, Baker BJ (2008) The chemistry of algal secondary metabolism. In: Amsler C D (Ed.) Algal chemical ecology. Springer Berlin Heidelberg,

Medeiros V, Queiroz K, Cardoso M, Monteiro G, Oliveira F, Chavante S, Guimaraes L, Rocha H, Leite E (2008) Sulfated galactofucan from Lobophora variegata: anticoagulant and anti-inflammatory properties. Biochemistry (Moscow) 73:1018-24

Miyake T, Shibamoto T (1995) Quantitative analysis by gas chromatography of volatile carbonyl compounds in cigarette smoke. J Chromatogr 693:376-81

Moo-Puc R, Robledo D, Freile-Pelegrin Y (2008) Evaluation of selected tropical seaweeds for in vitro anti-trichomonal activity. J Ethnopharmacol 120:92-97

Moo-Puc R, Robledo D, Freile-Pelegrín Y (2009) In vitro cytotoxic and antiproliferative activities of marine macroalgae from Yucatán, Mexico Actividad citotóxica y antiproliferativa in vitro de macroalgas marinas de Yucatán, México. Cienc Mar 35:345-58 
Morrow K, Paul V, Liles M, Chadwick N (2011) Allelochemicals produced by Caribbean macroalgae and cyanobacteria have species-specific effects on reef coral microorganisms. Coral Reefs 30:309-20

Morrow KM, Ritson-Williams R, Ross C, Liles MR, Paul VJ (2012) Macroalgal extracts induce bacterial assemblage shifts and sublethal tissue stress in Caribbean corals. PLoS One 7:e44859

Morse AN, Iwao K, Baba M, Shimoike K, Hayashibara T, Omori M (1996) An ancient chemosensory mechanism brings new life to coral reefs. Biol J Bull 191:14954

Mota da Silva V, Da Cunha Veloso MC, Teixeira Sousa E, Vieira Santos G, Accioly MC, Afonso De Pereira P, De Andrade JB (2006) Determination of 11 lowmolecular-weight carbonyl compounds in marine algae by high-performance liquid chromatography. J Chromatogr Sci 44:233-38

Paiva AAdO, Castro AJ, Nascimento MS, Will LSE, Santos ND, Araújo RM, Xavier CA, Rocha FA, Leite EL (2011) Antioxidant and anti-inflammatory effect of polysaccharides from Lobophora variegata on zymosan-induced arthritis in rats. Int Immunopharmacol 11:1241-50

Paul VJ, Puglisi MP, Ritson-Williams R (2006) Marine chemical ecology. Nat Prod Rep 23:153-80

Paul VJ, Ritson-Williams R (2008) Marine chemical ecology. Nat Prod Rep 25:66295

Plaza M, Cifuentes A, Ibáñez E (2008) In the search of new functional food ingredients from algae. Trends Food Sci Technol 19:31-39

Queiroz K, Assis C, Medeiros V, Rocha H, Aoyama H, Ferreira C, Leite E (2006) Cytotoxicity effect of algal polysaccharides on HL60 cells. Biochemistry (Moscow) 71:1312-15

Queiroz K, Medeiros V, Queiroz L, Abreu L, Rocha H, Ferreira C, Juca M, Aoyama $H$, Leite $E$ (2008) Inhibition of reverse transcriptase activity of HIV by polysaccharides of brown algae. Biomed Pharmacother 62:303-07

Rao CK, Untawale A (1991) Polyphenols content of Indian seaweeds. Mahasagar 24:99-102

Rasher DB, Hay ME (2010a) Chemically rich seaweeds poison corals when not controlled by herbivores. Proc Natl Acad Sci U S A 107:9683-88

Rasher DB, Hay ME (2010b) Seaweed allelopathy degrades the resilience and function of coral reefs. Commun Integr Biol 3:564-66

Rigotti A (2007) Absorption, transport, and tissue delivery of vitamin E. Mol Aspects Med 28:423-36

Rocha FD, Soares AR, Houghton PJ, Pereira RC, Kaplan MAC, Teixeira VL (2007) Potential cytotoxic activity of some Brazilian seaweeds on human melanoma cells. Phytother Res 21:170-75

Sathyaseelan T, Murugesan S, Sivamurugan V (2015) Structural identification and antioxidant properties of methanolic extract of brown algae Lobophora variegata (JVF Lamouroux) Womersley ex EC Oliveira. Int J Innov Pharma Biosci Res Technol 2:165-78

Siqueira RC, da Silva MS, de Alencar DB, Pires AdF, de Alencar NM, Pereira MG, Cavada BS, Sampaio AH, Farias WR, Assreuy AMS (2011) In vivo antiinflammatory effect of a sulfated polysaccharide isolated from the marine brown algae Lobophora variegata. Pharm Biol 49:167-74

Sivakumar S (2014) In vitro activity of seaweed extracts collected from Gulf of Mannar coast islands Tamilnadu on clinical isolates. Int J Pharm Biol Arch 5

Slattery M, Lesser MP (2014) Allelopathy in the tropical alga Lobophora variegata (Phaeophyceae): mechanistic basis for a phase shift on mesophotic coral reefs? J Phycol 50:493-505

Soares AR, Robaina M, Mendes GS, Silva TS, Gestinari L, Pamplona OS, Yoneshigue-Valentin Y, Kaiser CR, Romanos MTV (2012) Antiviral activity of 
extracts from Brazilian seaweeds against herpes simplex virus. Rev Bras Farmacogn 22:714-23

Sousa MBd, Pires KMdS, Alencar DBd, Sampaio AH, Saker-Sampaio S (2008) aand $\beta$-carotene, and $\alpha$-tocopherol in fresh seaweeds. Food Sci Technol (Campinas) 28:953-58

Stern JL, Hagerman AE, Steinberg PD, Mason PK (1996) Phlorotannin-protein interactions. J Chem Ecol 22:1877-99

Sun Z, Hanyuda T, Lim P-E, Tanaka J, Gurgel CFD, Kawai H (2012) Taxonomic revision of the genus Lobophora (Dictyotales, Phaeophyceae) based on morphological evidence and analyses $r b c \mathrm{~L}$ and cox3 gene sequences. Phycologia 51:500-12

Targett NM, Arnold TM (1998) Minireview-predicting the effects of brown algal phlorotannins on marine herbivores in tropical and temperate oceans. $J$ Phycol 34:195-205

Thennarasan S (2015) Biochecmial composition of marine brown alga Lobophora variegata from Mandapam in the South East Coast of Tamil Nadu. Int J Pharm Pharm Sci 5:25-29

Thrasher JD, Kilburn KH (2001) Embryo toxicity and teratogenicity of formaldehyde. Arch Environ Health: Int J 56:300-11

Val A, Platas G, Basilio A, Cabello A, Gorrochategui J, Suay I, Vicente F, Portillo E, Río M, Reina G (2001) Screening of antimicrobial activities in red, green and brown macroalgae from Gran Canaria (Canary Islands, Spain). Int Microbiol 4:35-40

Vallim MA, De Paula JC, Pereira RC, Teixeira VL (2005) The diterpenes from Dictyotacean marine brown algae in the Tropical Atlantic American region. Biochem Syst Ecol 33:1-16

Vieira C (2015) Lobophora biotic interactions and diversification. Ph. D. Doctoral dissertation, Ph. D. thesis, Université Pierre et Marie Curie, France.

Vieira C, D'hondt S, De Clerck O, Payri CE (2014) Toward an inordinate fondness for stars, beetles and Lobophora? Species diversity of the genus Lobophora (Dictyotales, Phaeophyceae) in New Caledonia. J Phycol 50:1101-19

Vieira C, Payri C, De Clerck O (2015) Overgrowth and killing of corals by the brown alga Lobophora hederacea (Dictyotales, Phaeophyceae) on healthy reefs in New Caledonia: a new case of the epizoism syndrome. Phycol Res 63:15253

Vieira C, Thomas OP, Culioli G, Houlbreque F, De Clerck O, Payri C (in revision) Allelopathic interactions between the brown algal genus Lobophora (Dictyotales, Phaeophyceae) and scleractinian corals. Scientific Reports

Wang H, Chiu L, Ooi VE, Ang PO (2008a) Seaweed polysaccharides with anticancer potential. Bot Mar 51:313-19

Wang H, Ooi EV, Ang Jr PO (2008b) Antiviral activities of extracts from Hong Kong seaweeds. J Zhejiang Univ-SCI A 9:969-76

Weidner K, Lages BG, da Gama BA, Molis M, Wahl M, Pereira RC (2004) Effects of mesograzer and nutrient levels on the induction of defenses in several Brazilian macroalgae. Mar Ecol Prog Ser:113-25

Zaneveld JS (1959) The utilization of marine algae in tropical South and East Asia. Econ Bot 13:89-131

Zubia M, Robledo D, Freile-Pelegrin Y (2007) Antioxidant activities in tropical marine macroalgae from the Yucatan Peninsula, Mexico. J Appl Phycol 19:449-58 
<smiles>CC(C)C(=O)c1c(O)cc(O)cc1O</smiles>

1-(2,4,6-trihydroxyphenyl)hexadecan-1-one (1)<smiles>O=C(O)CC(COc1ccccc1)OCC1OC(O)C(O)C(O)C1CS(=O)(=O)O</smiles>

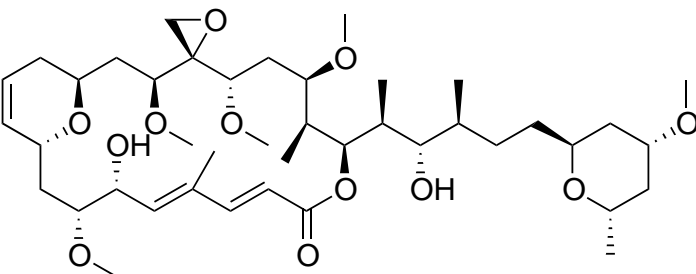

Lobophorolide (2)<smiles>[R]C(C=C)[C@@H](O)C/C=C\C/C=C\C/C=C\C/C=C\CCCC=[Pt]</smiles><smiles>[R6]c1cc(Br)c(O)c(Br)c1</smiles>
Bromophenol $R_{1} \quad R_{2} \quad R_{3}$<smiles>CCCCCCCCCCCC1=C(C(C)=O)C(=O)CC(O)C1</smiles><smiles>[2H]c1cc(O)c(C(C)=O)c(CCCCCCCCCCC)c1</smiles>

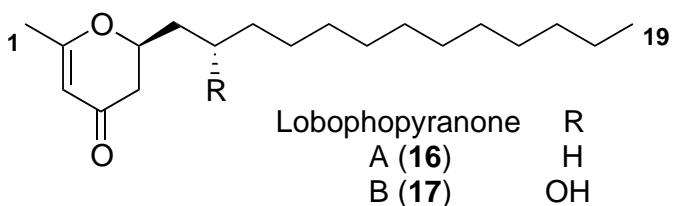

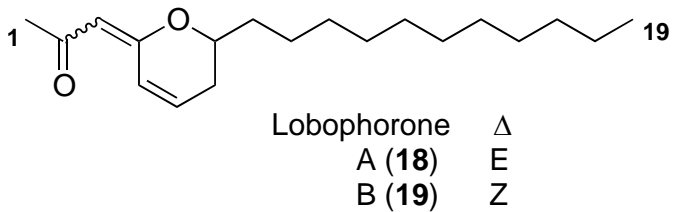<smiles>CC(=O)C[C@@H](O)CCCCCCCCCC[13CH3]</smiles><smiles>CC(=O)C=CCC(O)CCCCCCCCC[123I]</smiles><smiles>CCOCCOCCOCCOCC</smiles>

Fig. 1 Chemical structure of the natural products isolated from different species of Lobophora (Cantillo-Ciau et al. 2010; Chung et al. 2003; Gerwick and Fenical 1982; Gutiérrez-Cepeda et al. 2015; Kubanek et al. 2003; Vieira et al. in revision). 